\title{
Physiological Responses of Turnip (Brassica rapa L. subsp. rapa) Seedlings to Salt Stress
}

\author{
Kai Jia, Cunyao Yan, Huizhuan Yan, and Jie Gao \\ College of Horticulture and Forestry, Xinjiang Agricultural University, \\ Urumqi, Xinjiang 830052, China
}

Additional index words. antioxidant enzyme, $\mathrm{NaCl}$, osmoregulation substances, reactive oxygen, seed germination

\begin{abstract}
Turnip (Brassica rapa $\mathrm{L}$. subsp. rapa) is a type of root vegetable belonging to the Brassica subspecies of Cruciferae. Salt stress is one of the main abiotic stresses that causes water deficit, ion toxicity, and metabolic imbalance in plants, seriously limiting plant growth and crop yield. Two commercial turnip cultivars, Wenzhoupancai and Qiamagu, were used to evaluate the seed germination and physiological responses of turnip seedlings to salt stress. $\mathrm{NaCl}$ was used to simulate salt stress. Parameters of seed germination, seedling growth, osmoregulation substances content, chlorophyll content, antioxidant enzyme activity, and other physiological parameters of turnip seedlings were measured after 7 days of salt stress. The results showed that salt stress reduced the seed germination rate, and that the seeds of 'Wenzhoupancai' were more sensitive to salt stress. Salt stress inhibited the growth of turnip seedlings. With the increased $\mathrm{NaCl}$ concentration, the seedling dry weight, seedling fresh weight, and seedling length of turnip decreased gradually. Under the salt stress treatment, the osmotic regulatory substances and antioxidant enzyme activity in the seedlings of turnip increased significantly. The chlorophyll content increased at a lower $\mathrm{NaCl}$ level, but it decreased when the level of $\mathrm{NaCl}$ was higher. Growth parameters of turnip seedlings had significant negative correlations with the reactive oxygen content, osmoregulation substances, and antioxidant enzyme activities, but they had positive correlations with chlorophyll $b$ and total chlorophyll content. These results indicated that salt stress-induced oxidative stress in turnip is mainly counteracted by enzymatic defense systems.
\end{abstract}

Turnip (Brassica rapa L. subsp. rapa) is a major root vegetable belonging to the Brassica subspecies of the family Cruciferae. It originated in Europe and was taken to Asia and Northern China during the ancient Greek and Roman periods (Basak et al., 2018; Liang et al., 2006). In China, turnips are widely cultivated in Zhejiang province, Xinjiang Uygur Autonomous Region, and QinghaiTibet Plateau (Ye, 1995). Leaves and fleshy roots of turnip are rich in vitamins $\mathrm{A}, \mathrm{C}, \mathrm{E}$, and $\mathrm{B}_{6}$, folic acid, copper, calcium, and dietary fiber (Moate et al., 2002; Parveen et al., 2015). In addition to being a type of

Received for publication 27 May 2020. Accepted for publication 2 July 2020.

Published online 18 September 2020.

This research was supported by the Key Laboratory of Biology and Genetic Improvement of Horticultural Crops, Ministry of Agriculture, P.R. China (IVF201701); Natural Science Project of University Scientific Research Plan of Xinjiang Autonomous Region (XJEDU2017S017); Postgraduate Innovation Project of Xinjiang Agricultural University (XJAUGRI2017001); and Xinjiang Uyghur Autonomous Region Key Discipline Fund of Horticulture Science (2016-10758-3).

J.G. and H.Y. are the corresponding authors. E-mail: ofc111@163.com or hzhyan1118@163. com.

This is an open access article distributed under the CC BY-NC-ND license (https://creativecommons. org/licenses/by-nc-nd/4.0/). vegetable, turnip is also used as an important source of feed for livestock (Moate et al., 2002; Neilsen et al., 2008).

Xinjiang is a major turnip production area in China where the soil is arid and salinized. After years of planting and breeding, turnip in Xinjiang has developed the unique characteristic of being tolerant to salt, alkali, and drought, which is quite different from turnips in other regions (Shi et al., 2011; Tuo, 2016).

Soil salinization is a major threat to global food security. Up to $20 \%$ of the world's irrigated land has been affected by salt stress (Abogadallah, 2010). The salinization area accounts for $32.07 \%$ of cultivated land in Xinjiang (Zhang et al., 2017). Salt stress is one of the main abiotic stresses; it causes water deficit, ion toxicity, metabolic imbalance, and limits plant growth and crop yield (Park et al., 2016; Ryu and Cho, 2015; Zhu, 2003). The antioxidant enzyme activity of plants has been considered to be related to salt tolerance in many studies (Abogadallah, 2010; Hannachi and Van Labeke, 2018; Noreen et al., 2010). Salt stress increases the antioxidant enzyme activity of plants because plants need to remove the reactive oxygen substances to avoid cell damage (Apel and Hirt, 2004). The most common target substances for the elimination of antioxidant enzymes are $\mathrm{O}_{2}{ }^{--}$and $\mathrm{H}_{2} \mathrm{O}_{2}$ under salt stress. In chloroplasts, mitochondria, cytoplasms, and peroxisomes, $\mathrm{O}_{2}^{-{ }^{-}}$is transformed to $\mathrm{H}_{2} \mathrm{O}_{2}$ by SOD, and $\mathrm{H}_{2} \mathrm{O}_{2}$ is detoxified by catalases and peroxidases (Abogadallah et al., 2010). Recently, the effects of salt stress on physiology and biochemistry of turnip plants have been studied. The results showed that salt stress significantly reduced the germination index of turnip seeds, inhibited plant growth, reduced plant length, reduced dry and fresh weights, reduced relative water content of leaves and chlorophyll content, and increased proline content (Jan et al., 2016). Salt stress also significantly improved the antioxidant enzyme activity of turnip plants and vitamin $\mathrm{C}$ content in leaves; however, high concentrations of $\mathrm{NaCl}$ (180 $\mathrm{mmol} / \mathrm{L}$ ) also caused irreversible damage to plants (Mojarad et al., 2016). Francois (1984) found that if the salt concentration in the soil were $30 \mathrm{mmol} / \mathrm{L}$, then the turnip yield would be reduced by $4.8 \%$. The effects of salt stress on turnip were focused on the later growth stage, but there is a lack of relevant reports of the seedling period, which is stage most sensitive to salt stress.

Our study was conducted to assess the effects of salt stress on the physiological and biochemical aspects of two turnip cultivars and to analyze the correlation between the morphological and physiological parameters. The findings of this investigation also clearly demonstrate the differences that occur with respect to various morphological, biochemical, and enzymatic changes in two turnip cultivars. The results may provide novel perspectives for exploring the salt tolerance mechanism of turnip seedlings and innovating salt tolerant germplasm resources.

\section{Materials and Methods}

\section{Plant materials}

Two commercial turnip (Brassica rapa subsp. rapa L.) cultivars, Wenzhoupancai (Zhejiang Xianfeng Seed Industry Co., Ltd., Jiaxing, China) and Qiamagu (Xinjiang Tiandihe Seed Industry Co., Ltd., Urumqi, China), were used as plant materials. Certified seeds of the two cultivars were purchased from local seed retailers. 'Qiamagu' was found to be a salt-tolerant turnip cultivar by Shi et al. (2011).

\section{Plant growth and treatments}

Expt. 1: Salt stress on seed germination. Seeds of turnips were sterilized using sodium hypochlorite $(5 \%)$ for $15 \mathrm{~min}$ and then rewashed with distilled water for $15 \mathrm{~min}$. Thereafter, seeds were placed on filter paper in $9-\mathrm{cm}$ petri dishes in which $5 \mathrm{~mL} \mathrm{NaCl}$ solution with different concentrations $(0,50$, 100,150 , and $200 \mathrm{mmol} / \mathrm{L}$ ) was added to simulate salt stress. Germination was assessed using three replicates of 50 seeds for each treatment. Petri dishes were placed in an incubator with a constant temperature of $25^{\circ} \mathrm{C}$ without light. After $7 \mathrm{~d}$ of germination, the germination parameters were examined.

Seed germination parameters. Seeds were considered germinated with the emergence of the radicle. Germination was scored as 
germinated when a 1-mm radicle had emerged from the seedcoat.

Germination rate $=($ Germinated seeds in each treatment/

Total number of germinated seeds) $\times 100 \%$

Germination potential $=($ Total germinated seeds in each treatment in the first day/

Total number of germinated seeds) $\times 100 \%$

Germination index

$=\sum$ (Germinated seeds in $\mathrm{t}$ days $/$

Number of germination days corresponding)

Salt-injury index

$=[($ Germination rate of control

- Germination rate in each treatment)/

Germination rate of control] $\times 100 \%$

Expt. 2: Salt stress on seedling growth. Seeds of turnips were sterilized and washed according to the method used for Expt. 1 and then germinated in distilled water. Germinated turnip seeds (1-mm radicle emerged from the seedcoat) were planted in plastic pots $(20 \times 12 \mathrm{~cm})$ with coconut fiber as the substrate. Every pot was planted with six seedlings. All of the pots were placed in the greenhouse where the temperature was maintained at $25 \pm 2{ }^{\circ} \mathrm{C} / 18 \pm 2{ }^{\circ} \mathrm{C}$ and the photoperiod was $16 \mathrm{~h} / 8 \mathrm{~h}$ (day/night). Each pot was irrigated with $50 \mathrm{~mL}$ of $1 / 2$ Hoagland nutrient solution every $3 \mathrm{~d}$.

Two-week-old (two leaves) turnip seedlings with uniform sizes were randomly divided into five treatment groups: 1) $1 / 2$ Hoagland solution (CK); 2) 1/2 Hoagland solution $+50 \mathrm{mmol} / \mathrm{L} \mathrm{NaCl}$; 3$) 1 / 2$ Hoagland solution $+100 \mathrm{mmol} / \mathrm{L} \mathrm{NaCl}$; 4) $1 / 2$ Hoagland solution $+150 \mathrm{mmol} / \mathrm{L} \mathrm{NaCl}$; and 5) $1 / 2$ Hoagland solution $+200 \mathrm{mmol} / \mathrm{L} \mathrm{NaCl}$. To avoid salt shock, $\mathrm{NaCl}$ was added in increments $(50 \mathrm{mmol} / \mathrm{L} / \mathrm{d})$ until the desired concentrations were reached. Each pot was irrigated by $50 \mathrm{~mL}$ solution of the respective treatment on alternate days. For each treatment, at least three pots of seedlings were used. After $7 \mathrm{~d}$ of treatment, the leaves of plants were harvested and growth parameters and physiology parameters of seedlings were examined and assessed. The entire experiment was conducted with respective salt treatments on 22 Apr. 2019, in the greenhouse at Xinjiang Agricultural University.

\section{Seedling growth parameters}

Shoots and roots were washed with distilled water and then gently blotted dry on a paper towel. Thereafter, the shoots and roots were separated to measure the fresh weight and then dried for $48 \mathrm{~h}$ at $70{ }^{\circ} \mathrm{C}$ to determine dry weight. Shoot length and root length were measured using a vernier caliper $(0.01 \mathrm{~mm})$.

\section{Antioxidant enzyme activity}

SOD activity was determined by inhibiting the photochemical reduction of nitroblue tetrazolium (NBT) at $560 \mathrm{~nm}$ (Giannopolitis and Ries, 1977). POD activity was measured by the guaiacol colorimetric method (Scebba et al., 2001). CAT activity was determined by using the ultraviolet absorption method (Patra et al., 1978). APX activity was measured according to the method of Dalton et al. (1996).

\section{MDA, $\mathrm{H}_{2} \mathrm{O}_{2}$ and $\mathrm{O}_{2}^{--}$content}

Lipid peroxidation was measured as the amount of malondialdehyde (MDA) determined by the thiobarbituric acid (TBA) reaction (Hodges et al., 1999). The $\mathrm{H}_{2} \mathrm{O}_{2}$ level was measured colorimetrically as described by Jana and Choudhuri (1982). The $\mathrm{O}_{2}{ }^{-}$ content was determined according to the method of Wang et al. (2008).

\section{Osmoregulation substances content}

Proline content was determined according to the method described by Bates (1973). The soluble protein content was estimated using bovine serum albumin as the standard (Bradford, 1976). Total soluble sugar was measured by using the rapid and convenient anthrone reagent method reported by Thimmaiah (2004).

\section{Chlorophyll content}

Determination of chlorophyll content in the leaves of turnip seedlings was performed by using the ethanol extraction method (Palta, 1990).

\section{Statistical analysis}

All statistical analyses were conducted using SPSS version 19.0 (IBM, Chicago, IL). Significant differences between treatments were evaluated by an analysis of variance (ANOVA). TB tools software (Chen et al., 2018) was used to draw the correlation analysis heatmap.

\section{Results}

Effects of salt stress on the germination process. Salt stress delayed the germination process of turnip seeds (Fig. 1). On the second day, the $200 \mathrm{mmol} / \mathrm{L} \mathrm{NaCl}$ treatment reached the rapid germination stage, whereas other treatments reached the rapid germination stage on the first day, and the gemination rate of all treatments tended to be stable on the third day. The rapid germination period of 'Qiamagu' seeds was not delayed with the increase of the $\mathrm{NaCl}$ concentration, and all treatments reached the rapid germination period on the first day (Fig. 1B). In addition to the $200 \mathrm{mmol} / \mathrm{L} \mathrm{NaCl}$ treatment, the germination rate of other treatments tended to be stable on the third day, and that of $200 \mathrm{mmol} /$ $\mathrm{L} \mathrm{NaCl}$ treatment group remained stable on the fourth day.

Effects of salt stress on germination parameters. The ANOVA results showed that turnip cultivars had a significant effect on all indexes of seed germination, indicating that cultivars were the key factors affecting germination indexes. The $\mathrm{NaCl}$ concentration had a significant effect on the germination rate, germination index, and salt injury index of turnip seeds, but there was no significant effect on the germination potential. Their interaction had no significant effect on the germination index of turnip seeds (Supplemental Table 1).

When the $\mathrm{NaCl}$ concentrations were 150 $\mathrm{mmol} / \mathrm{L}$ and $200 \mathrm{mmol} / \mathrm{L}$, the germination rate of 'Wenzhoupancai' seed decreased significantly by $29.90 \%$ and $57.80 \%$, respectively, compared with the control. The germination potential decreased significantly, by $46.80 \%$, at $200 \mathrm{mmol} / \mathrm{L}$. With the increased $\mathrm{NaCl}$ concentration, the salt injury index of 'Wenzhoupancai' gradually increased. When the $\mathrm{NaCl}$ concentrations were $150 \mathrm{mmol} / \mathrm{L}$ and $200 \mathrm{mmol} / \mathrm{L}$, the salt injury index values increased significantly by $24.43 \%$ and $28.87 \%$, respectively. The germination rate of 'Qiamagu' seeds was not significantly different between $\mathrm{NaCl}$ treatment and the control. The germination potential significantly decreased by $11.10 \%$ with the $200 \mathrm{mmol} / \mathrm{L} \mathrm{NaCl}$ treatment. The germination index decreased significantly, by $6.28 \%$ and $8.38 \%$, when the $\mathrm{NaCl}$ concentrations were $150 \mathrm{mmol} / \mathrm{L}$ and $200 \mathrm{mmol} / \mathrm{L}$, respectively, compared with the control. In addition, the salt injury index values of these two treatment concentrations were higher than that of the control, but there was no significant difference (Table 1).

Effects of salt stress on growth parameters. According to the ANOVA results, turnip cultivars, salinity, and their interaction had a significant effect on the shoot length, root length, shoot weight, and root weight of turnip seedlings (Supplemental Table 1). With the increased $\mathrm{NaCl}$ concentration, the shoot length, root length, fresh shoot weight, fresh root weight, and dry weight of 'Wenzhoupancai' decreased
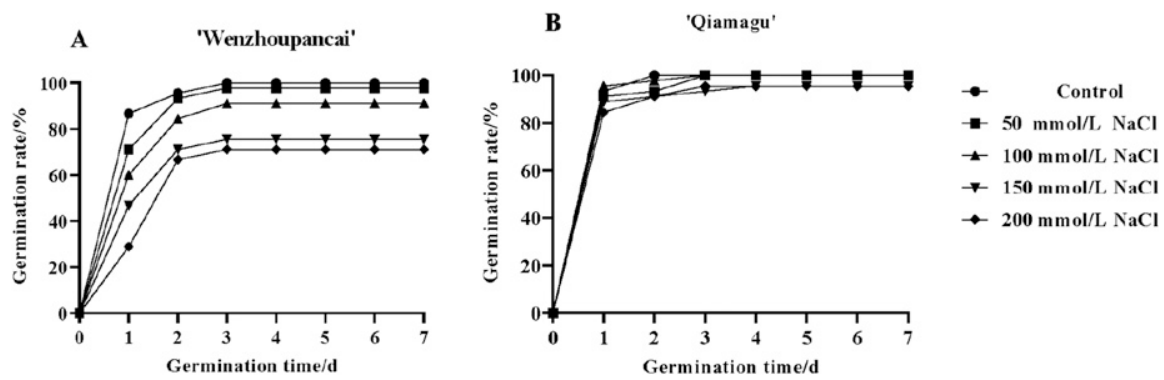

Fig. 1. Effects of salt stress on the germination process of turnip seeds. 
Table 1. Effects of salt stress on the germination of turnip seeds.

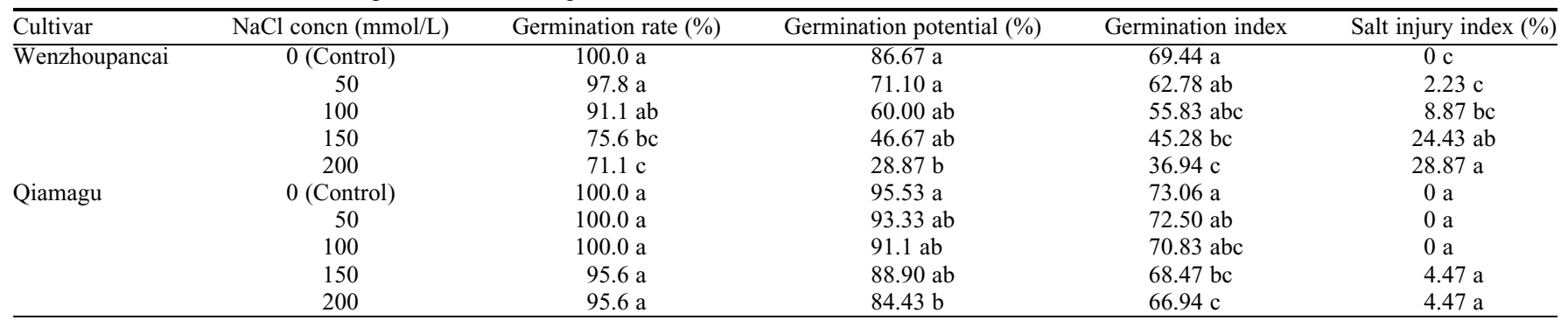

Data are shown as the mean of three biological replicates. Different letters show significant differences among five salt stress treatments at $P<0.05$.

gradually and reached the lowest level with $200 \mathrm{mmol} / \mathrm{L}$; these decreased by $79.14 \%$, $75.97 \%, 79.79 \%, 78.95 \%$, and $63.64 \%$, respectively. Similarly, the shoot length, root length, fresh shoot weight, fresh root weight, and dry weight of plants of 'Qiamagu' also reached the lowest level with $200 \mathrm{mmol} / \mathrm{L}$; these decreased by $81.97 \%, 83.31 \%, 79.39 \%$, $66.67 \%$, and $60.00 \%$, respectively (Table 2 ).

Effects of salt stress on $\mathrm{MDA}, \mathrm{H}_{2} \mathrm{O}_{2}$, and $\mathrm{O}_{2}^{--}$contents. According to the ANOVA results (Supplemental Table 1), turnip cultivars and salinity had significant effects on MDA and $\mathrm{O}_{2}{ }^{-}$content, whereas the interaction between them had no significant effect on MDA. There was no significant effect of turnip cultivars on the $\mathrm{H}_{2} \mathrm{O}_{2}$ content, but salinity and their interaction had a significant effect on the $\mathrm{H}_{2} \mathrm{O}_{2}$ content. The interaction of turnip cultivars and salinity only had a significant effect on the $\mathrm{O}_{2}^{--}$content. With the increased $\mathrm{NaCl}$ concentration, the MDA content in the leaves of seedlings showed a trend of increasing to a maximum value and then decreasing, whereas the $\mathrm{H}_{2} \mathrm{O}_{2}$ and $\mathrm{O}_{2}^{--}$contents showed a trend of gradually increasing (Fig. 2).

The MDA content of 'Wenzhoupancai' and 'Qiamagu' reached its highest when the $\mathrm{NaCl}$ concentration was $150 \mathrm{mmol} / \mathrm{L}$; it increased by $335.54 \%$ and $264.03 \%$, respectively, compared with the control. Low $\mathrm{NaCl}$ concentrations had no significant effect on the $\mathrm{H}_{2} \mathrm{O}_{2}$ content of 'Wenzhoupancai', which increased significantly when the $\mathrm{NaCl}$ concentration was $150 \mathrm{mmol} / \mathrm{L}$ and reached its highest value with $200 \mathrm{mmol} / \mathrm{L}$; it increased by $643.62 \%$. With the increased $\mathrm{NaCl}$ concentration, the content of $\mathrm{H}_{2} \mathrm{O}_{2}$ in 'Qiamagu' increased significantly. When the $\mathrm{NaCl}$ concentration was $200 \mathrm{mmol} / \mathrm{L}, \mathrm{H}_{2} \mathrm{O}_{2}$ reached its highest level, which increased by $187.44 \%$ compared with the control. The content of $\mathrm{O}_{2}{ }^{-}$in the leaves of two turnip cultivars increased significantly under salt stress; it reached its highest level with $200 \mathrm{mmol} / \mathrm{L}$ and increased by $262.05 \%$ and $132.52 \%$ compared with the control.

Effects of salt stress on antioxidant enzyme activity. According to the ANOVA results (Supplemental Table 1), turnip cultivars, salinity, and their interaction had significant effects on SOD and CAT activity. Turnip cultivars and their interaction had no significant effects on POD activity, but salinity had a significant effect on POD activity. Turnip cultivars and salinity had significant effects on APX activity, but their interaction had no effect on APX activity. The SOD activity of 'Wenzhoupancai' reached the maximum value at the $\mathrm{NaCl}$ concentration of $200 \mathrm{mmol} / \mathrm{L}$; it increased by $102.60 \%$ compared with the control (Fig. 3). The SOD activity of 'Qiamagu' increased significantly under salt stress and reached its highest level at $200 \mathrm{mmol} / \mathrm{L}$; it increased by $84.73 \%$ compared with the control. Under salt stress, the POD activity in leaves of turnip seedlings increased significantly. The POD activity of 'Wenzhoupancai' and 'Qiamagu' reached the maximum with $200 \mathrm{mmol} / \mathrm{L}$; it increased by $828.30 \%$ and $476.97 \%$, respectively. With the increased $\mathrm{NaCl}$ concentration, the CAT activity of 'Wenzhoupancai' increased gradually. With $200 \mathrm{mmol} / \mathrm{L}$, the CAT activity reached its maximum value; it increased by $179.12 \%$ compared with the control. With the increased $\mathrm{NaCl}$ concentration, the CAT activity in the leaves of 'Qiamagu' seedlings increased to its maximum value and then decreased. When the $\mathrm{NaCl}$ concentration was $150 \mathrm{mmol} / \mathrm{L}$, CAT activity reached its highest level; it increased by $51.36 \%$ compared with the control. The APX activity in the leaves of turnip seedlings of the two cultivars was significantly increased with 200 $\mathrm{mmol} / \mathrm{L}$; it increased by $102.60 \%$ and $177.37 \%$ respectively. However, it was not significantly increased with other $\mathrm{NaCl}$ concentrations. In general, the increased antioxidant enzyme activity of 'Wenzhoupancai' was higher than that of 'Qiamagu' under salt stress.

Effects of salt stress on chlorophyll content. According to the ANOVA results (Supplemental Table 1), turnip cultivars, salinity, and their interaction had significant effects on the chlorophyll a, chlorophyll b, and total chlorophyll contents of turnip seedling leaves. With the increased $\mathrm{NaCl}$ concentration, the chlorophyll a, chlorophyll $\mathrm{b}$, and total chlorophyll contents of "Wenzhoupancai' increased to the maximum value and then decreased (Fig. 4). When the $\mathrm{NaCl}$ concentration was $100 \mathrm{mmol} / \mathrm{L}$, the chlorophyll a, chlorophyll $\mathrm{b}$, and total chlorophyll contents in the leaves of the seedlings reached their highest levels and increased by $43.67 \%$, $62.88 \%$, and $47.85 \%$, respectively, compared with the control. With the increased $\mathrm{NaCl}$ concentration, the chlorophyll a and total chlorophyll contents in 'Qiamagu' increased to their maximum and then decreased. They reached their highest value when the $\mathrm{NaCl}$ concentration was $50 \mathrm{mmol} /$ $\mathrm{L}$ and increased by $12.06 \%$ and $8.26 \%$, respectively, compared with the control The chlorophyll b content gradually decreased with the increased $\mathrm{NaCl}$ concentration. When the $\mathrm{NaCl}$ concentration was 200 $\mathrm{mmol} / \mathrm{L}$, chlorophyll $\mathrm{b}$ reached its lowest value and decreased by $40.86 \%$ compared with the control.

Effects of salt stress on osmoregulation substances content. According to the ANOVA results (Supplemental Table 1),

Table 2. Effects of salt stress on growth parameters of turnip seedlings.

\begin{tabular}{|c|c|c|c|c|c|c|}
\hline$\overline{\text { Cultivar }}$ & $\mathrm{NaCl}$ concn $(\mathrm{mmol} / \mathrm{L})$ & Shoot length $(\mathrm{cm})$ & Root length (cm) & Shoot wt (g) & Root wt (g) & Plant dry wt (g) \\
\hline & 0 (Control) & $4.17 \pm 0.94 \mathrm{a}$ & $3.87 \pm 0.63 \mathrm{a}$ & $0.094 \pm 0.011 \mathrm{a}$ & $0.019 \pm 0.005 \mathrm{a}$ & $0.011 \pm 0.001 \mathrm{a}$ \\
\hline \multirow{5}{*}{ Wenzhoupancai } & 50 & $3.65 \pm 0.37 \mathrm{a}$ & $3.75 \pm 0.79 b$ & $0.067 \pm 0.020 \mathrm{~b}$ & $0.018 \pm 0.008 \mathrm{a}$ & $0.009 \pm 0.001 \mathrm{~b}$ \\
\hline & 100 & $2.53 \pm 0.24 b$ & $3.01 \pm 0.54 \mathrm{c}$ & $0.037 \pm 0.009 \mathrm{c}$ & $0.019 \pm 0.005 \mathrm{a}$ & $0.006 \pm 0.001 \mathrm{c}$ \\
\hline & 150 & $1.29 \pm 0.18 \mathrm{c}$ & $1.75 \pm 0.22 \mathrm{~d}$ & $0.031 \pm 0.006 \mathrm{c}$ & $0.007 \pm 0.004 \mathrm{~b}$ & $0.004 \pm 0.001 \mathrm{~cd}$ \\
\hline & 200 & $0.87 \pm 0.26 \mathrm{~d}$ & $0.93 \pm 0.15 \mathrm{e}$ & $0.019 \pm 0.004 \mathrm{~d}$ & $0.004 \pm 0.002 \mathrm{~b}$ & $0.002 \pm 0.000 \mathrm{~d}$ \\
\hline & 0 (Control) & $6.60 \pm 1.66 \mathrm{a}$ & $6.05 \pm 0.64 \mathrm{a}$ & $0.131 \pm 0.016 \mathrm{a}$ & $0.021 \pm 0.004 \mathrm{a}$ & $0.005 \pm 0.003 \mathrm{a}$ \\
\hline \multirow[t]{4}{*}{ Qiamagu } & 50 & $4.42 \pm 1.19 b$ & $3.96 \pm 0.57 b$ & $0.093 \pm 0.009 b$ & $0.018 \pm 0.003 \mathrm{ab}$ & $0.004 \pm 0.001 \mathrm{~b}$ \\
\hline & 100 & $4.19 \pm 0.57 b$ & $3.48 \pm 0.33 \mathrm{c}$ & $0.072 \pm 0.006 \mathrm{c}$ & $0.017 \pm 0.003 \mathrm{ab}$ & $0.004 \pm 0.001 \mathrm{~b}$ \\
\hline & 150 & $1.25 \pm 0.54 \mathrm{c}$ & $1.77 \pm 0.43 \mathrm{~d}$ & $0.033 \pm 0.004 \mathrm{~d}$ & $0.014 \pm 0.004 \mathrm{~b}$ & $0.003 \pm 0.000 \mathrm{c}$ \\
\hline & 200 & $1.19 \pm 0.33 \mathrm{c}$ & $1.01 \pm 0.35 \mathrm{e}$ & $0.027 \pm 0.005 \mathrm{~d}$ & $0.007 \pm 0.001 \mathrm{c}$ & $0.002 \pm 0.001 \mathrm{~d}$ \\
\hline
\end{tabular}

Data are shown as the mean of three biological replicates. Different letters show significant differences among five salt stress treatments at $P<0.05$. 

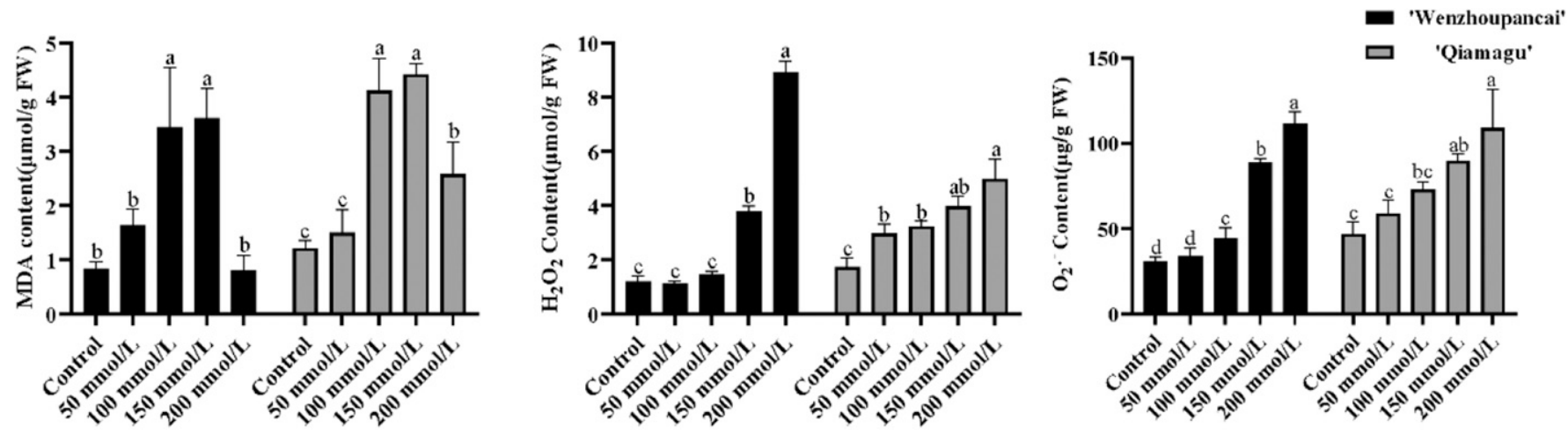

Fig. 2. Effects of salt stress on MDA, $\mathrm{H}_{2} \mathrm{O}_{2}$, and $\mathrm{O}_{2}{ }^{-}$contents in leaves of turnip seedlings. Bars with different letters show significant differences among five salt stress treatments at $P<0.05$.

turnip cultivars had no significant effects on the proline content in the leaves of turnip seedling, but they had significant effects on soluble sugar and soluble protein. However, salt stress had significant effects on soluble sugar, soluble protein, and proline of the two cultivars. Their interaction had significant effects on the content of soluble sugar, soluble protein, and proline. The proline content of 'Wenzhoupancai' increased significantly when the $\mathrm{NaCl}$ concentration was 150 $\mathrm{mmol} / \mathrm{L}$, and it reached its highest level when $\mathrm{NaCl}$ was $200 \mathrm{mmol} / \mathrm{L}$; it increased by $239.75 \%$ compared with the control. The proline content of 'Qiamagu' was the highest with $200 \mathrm{mmol} / \mathrm{L} \mathrm{NaCl}$; it increased by $264.86 \%$ compared with the control. With the increased $\mathrm{NaCl}$ concentration, the soluble sugar content gradually increased (Fig. 5). When the $\mathrm{NaCl}$ concentration was $200 \mathrm{mmol} / \mathrm{L}$, the soluble sugar content reached its highest level; it increased by $518.57 \%$ and $428.53 \%$, respectively, compared with the control. With the increased $\mathrm{NaCl}$ concentration, the soluble protein of 'Wenzhoupancai' increased to its maximum value and then decreased, but there was no significant difference in the content of soluble protein of each treatment under salt stress. When the $\mathrm{NaCl}$ concentration was $100 \mathrm{mmol} / \mathrm{L}$, the content of soluble protein was its highest; it increased by 98.81\% compared with the control. The content of soluble protein of 'Qiamagu' seedlings increased gradually with the increased $\mathrm{NaCl}$ concentration; it reached its highest level when the $\mathrm{NaCl}$ concentration was $200 \mathrm{mmol} / \mathrm{L}$ and increased by $111.74 \%$ compared with the control.

Correlations between growth and physiological parameters. As shown in
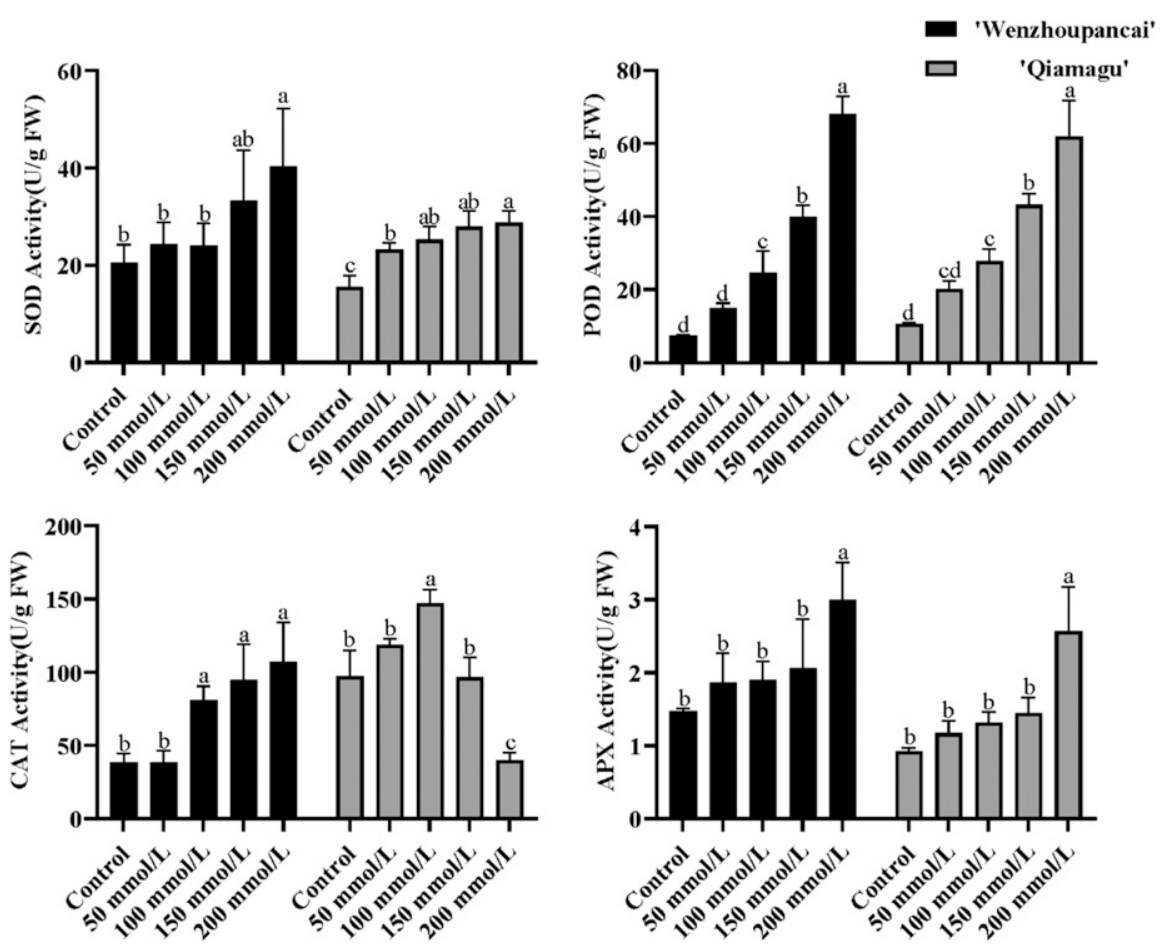

Fig. 3. Effects of salt stress on antioxidant enzyme activities in leaves of turnip seedlings. Bars with different letters show significant differences among five salt stress treatments at $P<0.05$.

Fig. 6, the growth parameter of turnip seedlings (shoot length, root length, shoot weight, and root weight) showed highly positive significant correlations $(r=0.64-0.96 ; P<$ 0.05-0.01) with each other. However, they had negative significant correlations with SOD, APX, soluble sugar, $\mathrm{O}_{2}^{--}$, proline, and POD $(r=-0.65-0.95 ; P<0.05-0.01)$. The dry weight of turnip seedlings showed strong negative significant correlations with soluble sugar, $\mathrm{H}_{2} \mathrm{O}_{2}, \mathrm{O}_{2}{ }^{--}$, proline, and POD $(r=$ $-0.76,-0.74,-0.87,-0.71$, and -0.78 , respectively; $P<0.05-0.01)$. SOD, APX, soluble sugar, $\mathrm{H}_{2} \mathrm{O}_{2}, \mathrm{O}_{2}{ }^{--}$, proline, and POD showed positive significant correlations $(r=$ $0.78-0.98 ; P<0.05-0.01)$ with each other. The MDA content had positive significant correlations with soluble protein $(r=0.64 ; P$ $<0.05)$ and chlorophyll b content $(r=0.64 ; P$ $<0.05)$. CAT activity only had positive significant correlations with chlorophyll b $(r=0.68 ; P<0.05)$ and total chlorophyll content $(r=0.64 ; P<0.05)$.

\section{Discussion}

Salt stress reduced the seed germination rate and delayed the process of seed germination (Meng et al., 2011). Salinity has an adverse effect on seed germination of plants by creating an osmotic potential outside the seed to inhibit the absorption of water or because of the toxic effect of $\mathrm{Na}^{+}$and $\mathrm{Cl}^{-}$. Noreen and Ashraf (2008) compared the effects of different $\mathrm{NaCl}$ concentrations on the germination of turnip seeds. The results showed that the seeds of 'Desi surakh', 'Purple top', and 'Golden bal' had certain tolerance to salt stress, and that the seed germination rates of the three turnip cultivars did not change significantly compared with the control under salt stress. The seed germination rates of 'Neela' and 'Peela' decreased significantly with the increased $\mathrm{NaCl}$ concentration. Shi et al. (2011) showed that the germination rate was significantly inhibited when the $\mathrm{NaCl}$ concentration exceeded 150 $\mathrm{mmol} / \mathrm{L}$, which was partially consistent with the results of our study. We found that there was no significant difference in the seed germination rate with $\mathrm{NaCl}$ treatment compared with the control in 'Qiamagu'. When 

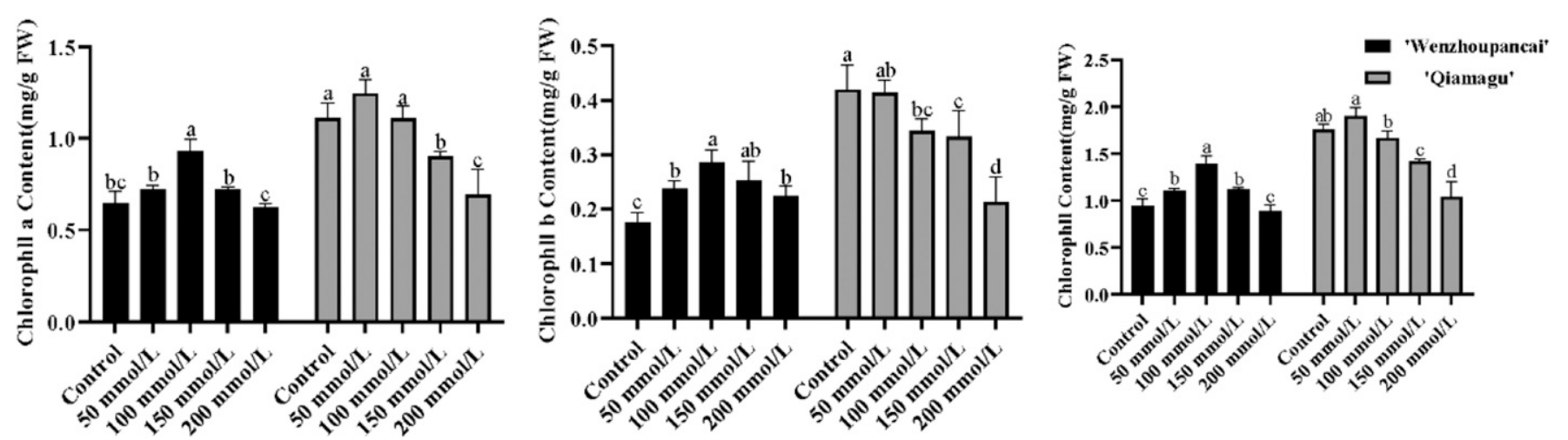

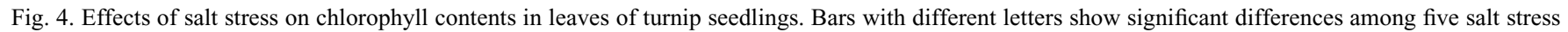
treatments at $P<0.05$.

the $\mathrm{NaCl}$ concentration was $200 \mathrm{mmol} / \mathrm{L}$, all germination indexes of 'Wenzhoupancai' were significantly different from those of the control; however, the germination rate and salt injury index of 'Qiamagu' were not significantly different from those of the control. This suggests that 'Wenzhoupancai' seeds are very sensitive to salt stress, and that 'Qiamagu' has a certain tolerance to salt stress. We concluded that the germination rate, germination potential, and germination index of turnip seeds can directly reflect their tolerance to salt stress.

Salt stress is one of the most common stresses and is a major abiotic stress that inhibits plant growth. It reduces the dry and fresh weights of plants and shortens the shoot length and root length through ion toxicity and osmotic stress (Park et al., 2016; Xiong et al., 2002; Zhu, 2016).

With the increased salt concentration, plant growth was inhibited more severely. Noreen et al. (2010) compared the changes in plant phenotypes of five turnip cultivars under salt stress. The results showed that 'Neela' and 'Peela' were more salt-tolerant than 'Purple top', 'Golden bal', and 'Desi surakh'. They also found that the decline in seedling growth of the two salt-tolerant cultivars was actually higher than that of other three cultivars. This was consistent with the results of our study, which showed that salt stress has an adverse effect on the growth of turnip seedlings. The weight and length of turnip seedlings gradually decreased with the increased $\mathrm{NaCl}$ concentration. The decreased seedling length of 'Wenzhoupancai' was less than that of 'Qiamagu' when subjected to salt stress, but the decline of other index values was higher than that of 'Qiamagu'.

Chlorophyll is the basic material for the photosynthesis of plants. Its function is to absorb and transmit light energy to ensure the proper photosynthesis of plants. Salt stress reduces photosynthesis, pigment bleaching, and chlorophyll content (Liu and Zhang, 2016; Shu et al., 2013; Taibi et al., 2016). Zeng et al. (2013) found that the chlorophyll content of Stevia rebaudiana leaves decreased with the increased salt concentration and reached its lowest value at $120 \mathrm{mmol} / \mathrm{L}$ $\mathrm{NaCl}$, which was partially contrary to the results of our study. We found that the chlorophyll content in the leaves of turnip seedlings increased to a maximum value and then decreased, and that the low salt concentration can significantly increase the chlorophyll content in plant leaves. Qiu et al. (2006) found that the chlorophyll content of salttolerant plants such as Rhaphiolepis umbellata (Thunb.), Morus alba L., and Rosa chinensis Jacq. seedlings increased to a maximum value at low salt concentrations and then decreased at high salt concentrations.
The results were consistent with those of our study. This may be because salt stress caused the binding between chlorophyll and chloroplast protein to become relaxed, and the relaxed chlorophyll was easily extracted, which led to the increased chlorophyll content under low salt concentrations (Romero-Aranda et al., 2001), and the higher salt concentrations damaged the permeability of plant cell membranes, which led to a large amount of chlorophyll molecule leakage (Halliwell, 1987).

When plants suffer from salt stress, the cell membrane is the main site of damage. When the cell membrane is damaged, a large amount of MDA will be produced, and the organic permeable substances in the cell fluid will flow out. Therefore, MDA is an important index used to measure the degree of membrane lipid damage (Davey et al., 2005). Noreen et al. (2010) found that salt stress reduced the MDA content of turnips; however, this conclusion was different from most others. Hannachi and Van Labeke (2018) found that the MDA content of eggplant increased with the increased $\mathrm{NaCl}$ concentration; this was consistent with the results of our study. We found that the MDA content increased at low $\mathrm{NaCl}$ concentrations and then decreased at high concentrations. The cause of the declining trend for MDA may be that that cell membrane suffers severely, resulting in MDA extravasation.
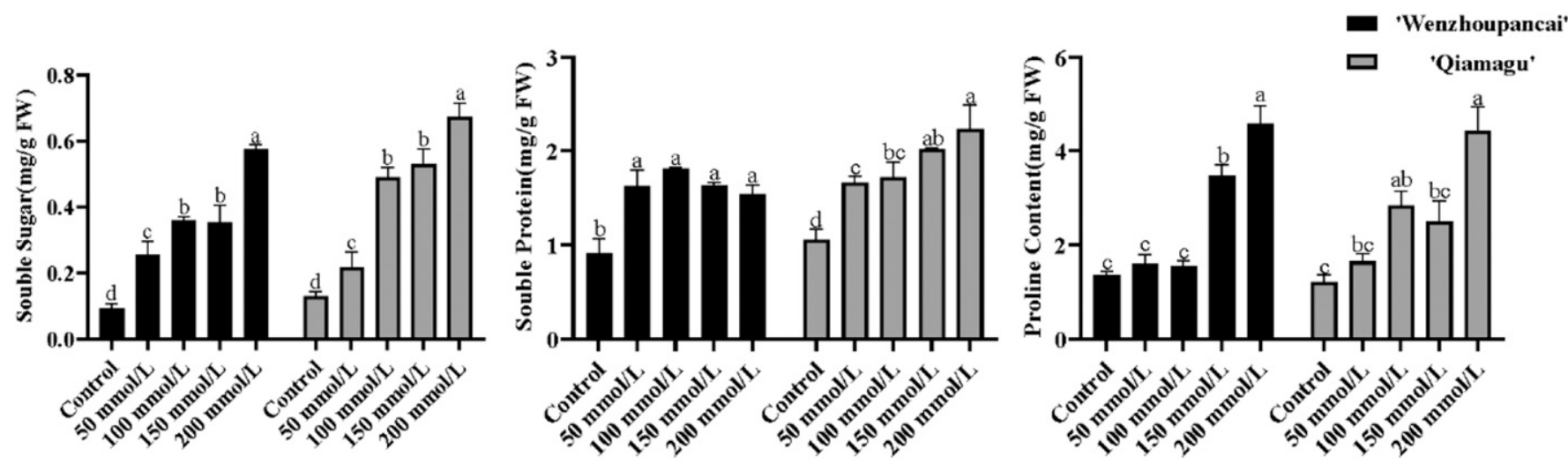

Fig. 5. Effects of salt stress on osmotic regulators in leaves of turnip seedlings. Bars with different letters show significant differences among five salt stress treatments at $P<0.05$. 


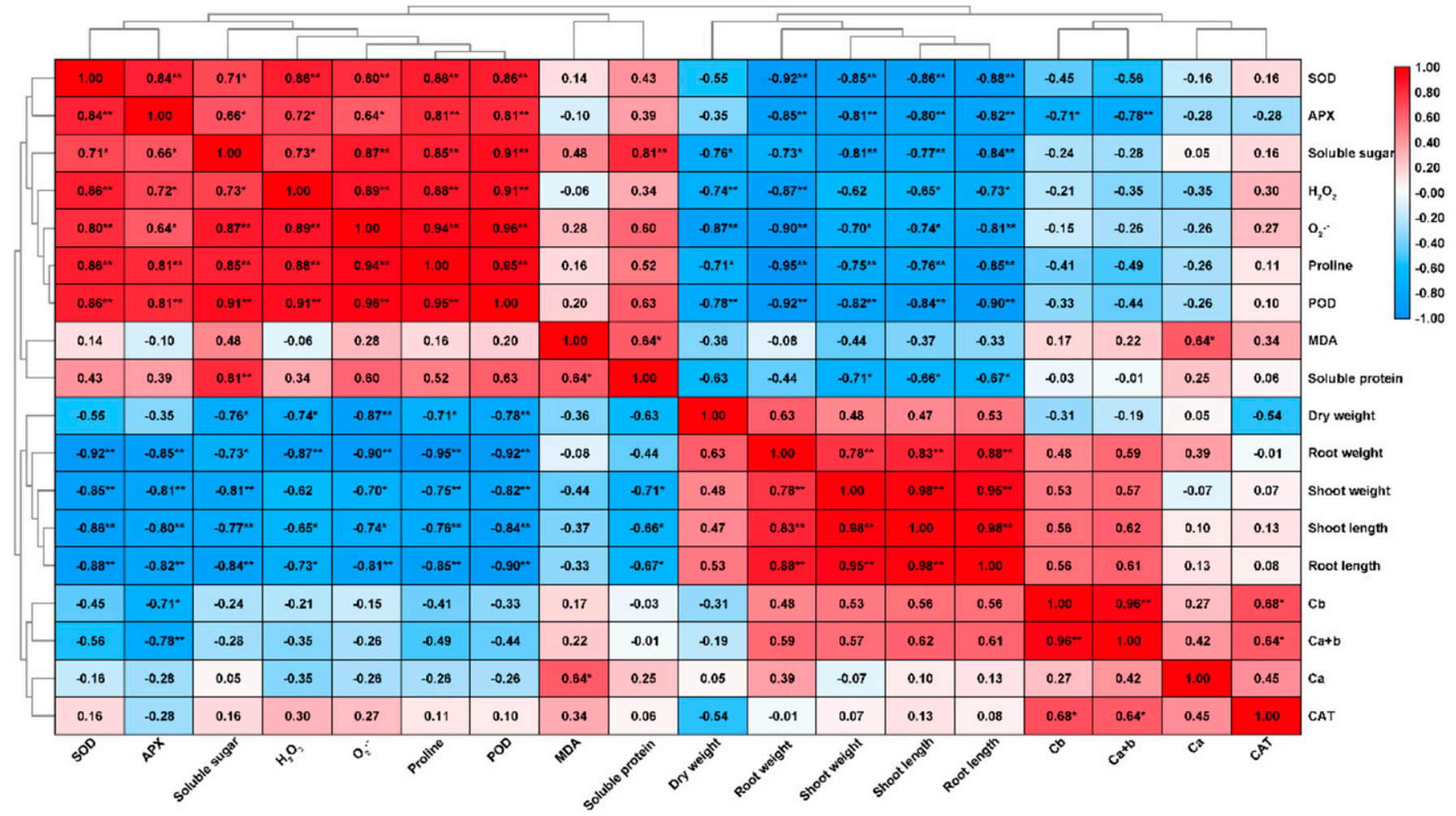

Fig. 6. Correlation between seedling growth and physiological parameters under salt stress. Numbers in the boxes represent the correlation coefficient value. Red represents a positive correlation and blue represents a negative correlation. * Significant difference at $P<0.05$. **Remarkably significant difference at $P<0.01$.

Salt stress enhances reactive oxygen metabolism in plants to $\mathrm{O}_{2}^{--}, \mathrm{H}_{2} \mathrm{O}_{2}$, and other substances. If these reactive oxygen species are not removed in time, they will destroy the normal metabolism of lipids, proteins, and nucleic acids and damage the plant cells (Das and Roychoudhury, 2014; Jithesh et al., 2006; Luo and Liu, 2011). Li (2009) found that with the increased $\mathrm{NaCl}$ concentration, the $\mathrm{O}_{2}{ }^{-}$content in tomato seedling leaves gradually increased. Yan et al. (2019) found that the $\mathrm{H}_{2} \mathrm{O}_{2}$ content in Morus mongolica Schneid. seedlings increased with the increased $\mathrm{NaCl}$ concentration. This is consistent with the results of our study, which showed that the contents of $\mathrm{H}_{2} \mathrm{O}_{2}$ and $\mathrm{O}_{2}$ in the leaves of turnip seedlings gradually increased with the increased $\mathrm{NaCl}$ concentration.

When plants are subjected to salt stress, their protection mechanism established by the antioxidant enzyme system, including SOD, POD, CAT, and APX enzymes, will enhance to reduce the $\mathrm{O}_{2}{ }^{--}$and $\mathrm{H}_{2} \mathrm{O}_{2}$ produced by reactive oxygen metabolism. Wang et al. (2017) found that with the increased $\mathrm{NaCl}$ concentration, the activity of SOD, POD, CAT, and APX enzymes in Beta vulgaris L. seedlings increased gradually. Zeng et al. (2013) also found the same trend for changes with the salt stress of Stevia rebaudiana seedlings. These results are consistent with our study. We found that the antioxidant enzymes increased rapidly when the turnip seedlings suffered salt stress.

When plants suffer from stress, they will regulate osmotic substances to resist salt stress. Osmoregulation substances in plants include proline, soluble sugar, and soluble protein. Li et al. (2018) found that the free proline content of Eremochloa opiuroides (Munro) increased significantly under salt stress, and that the variation in soluble protein was closely related to the tolerance degree of salt stress. The content of soluble protein in salt-tolerant cultivars increased significantly, but that in salt-sensitive cultivars decreased significantly. Li et al. (2017) showed that under salt stress, the soluble sugar content of salt-tolerant cultivars increased significantly compared to that of salt-sensitive cultivars, and the soluble sugar content of salt-tolerant cultivars was also significantly higher than that of salt-sensitive cultivars. In our study, with the increased $\mathrm{NaCl}$ concentration, the soluble sugar content, soluble protein content, and proline content in the leaves of turnip seedlings increased significantly. Therefore, we concluded that turnip seedlings would resist the damage of salt stress by regulating their osmotic substances and maintaining osmotic balance.

A correlation analysis can reveal the synergism among the parameters of plants under salt stress. Keskin and Yasar (2007) found that the shoot length, root length, shoot fresh weight, and root fresh weight of eggplant (Solanum melongena L.) plants decreased significantly when the plants were subjected to $150 \mathrm{mmol} / \mathrm{L} \mathrm{NaCl}$ stress for $14 \mathrm{~d}$. Statistically significant positive correlations were found for four growth parameters. The results were consistent with those of our study, which indicated that the phenotypic changes of the shoot and root of the plants were synchronous under salt stress. Yasin et al. (2017) found that the contents of soluble sugar and soluble protein in Raphanus sativus L. increased significantly under salt stress. There was a significant positive correlation between these two characteristics under salt stress. The reason for this phenomenon may be that plants need to regulate the contents of osmotic substances to resist the osmotic stress caused by salt stress. Chunthaburee et al. (2016) found that the $\mathrm{H}_{2} \mathrm{O}_{2}$ content had a significant positive correlation with POD activity in rice seedlings under salt stress. We found that there were significant positive correlations among $\mathrm{H}_{2} \mathrm{O}_{2}$ content, $\mathrm{O}_{2}{ }^{--}$content, and the activities of SOD, POD, and APX in turnip seedlings under salt stress. We concluded that turnip seedlings would enhance the activities of antioxidant enzymes to resist the damage to plant cells caused by the production of reactive oxygen under salt stress. Ashraf et al. (2013) found that there was a significant positive correlation with plant height and the chlorophyll content in mungbean (Vigna radiata L.) plants under salt stress. Although the correlations between chlorophyll content and phenotypic parameters of turnip seedlings were not significant in our study, there was still a positive correlation trend. Liu and Zhang (2016) found that the correlations between total chlorophyll content and antioxidant enzyme activities in Potentilla fruticosa $\mathrm{L}$. were uncertain after $7 \mathrm{~d}$ of salt stress. The chlorophyll content was positively correlated with SOD activity but negatively correlated with POD activity. The 
same conclusion was found in our study. We found that the total chlorophyll content and APX activity of turnip seedlings were negatively correlated with CAT activity under salt stress. We hypothesized that the synthesis of chlorophyll was controlled by many factors under salt stress.

\section{Conclusion}

In this study, salt stress inhibited the germination of turnip seeds, restricted the growth of seedlings, and reduced the chlorophyll content in the leaves of turnip seedlings. To alleviate the damage of salt stress, turnip seedlings would enhance the activities of antioxidant enzymes to remove the reactive oxygen and modify the contents of soluble sugar, soluble protein, and proline to regulate the osmotic potential. Statistically negative correlations were found between the growth parameters and antioxidant enzyme activities. There was a positive correlation among growth parameters. The results of this study suggest that salt stress induces the inhibition of turnip seedling growth. We concluded that 'Qiamagu' was highly tolerant of salt stress, and that 'Wenzhoupancai' was somewhat less tolerant than 'Qiamagu'. These findings could benefit the cultivation of this plant.

\section{Literature Cited}

Abogadallah, G.M. 2010. Antioxidative defense under salt stress. Plant Signal. Behav. 5(4):369-374.

Abogadallah, G.M., M.M. Serag, and W.P. Quick. 2010. Fine and coarse regulation of reactive oxygen species in the salt tolerant mutants of barnyard grass and their wild-type parents under salt stress. Physiol. Plant. 138(1):60-73.

Apel, K. and H. Hirt. 2004. Reactive oxygen species: Metabolism, oxidative stress, and signal transduction. Annu. Rev. Plant Biol. 55(1):373-399.

Ashraf, M.A., M. Rasool, Q. Ali, M.Z. Haider, A. Noman, and M. Azeem. 2013. Salt-induced perturbation in growth, physiological attributes, activities of antioxidant enzymes and organic solutes in mungbean (Vigna radiata L.) cultivars differing in salinity tolerance. Arch. Agron. Soil Sci. 59(12):1695-1712.

Bates, L.S., R.P. Waldren, and I.D . Teare. 1973. Rapid determination of free proline for waterstress studies. Plant Soil 39:205-207.

Basak, S., G. Wang, X. Sun, and Y. Yang. 2018. Variations in genome size of turnip landraces from two high-altitude environments. J. Amer. Soc. Hort. Sci. 143:136-143.

Bradford, M.M. 1976. A rapid and sensitive method for the quantitation of microgram quantities of protein utilizing the principle of protein-dye binding. Anal. Biochem. 72(12):248-254.

Chen, C., R. Xia, H. Chen, and Y. He. 2018. TBtools, a Toolkit for Biologists integrating various HTS-data handling tools with a userfriendly interface. bioRxiv, doi: 10.1101/ 289660.

Dalton, D.A., L.D. del Castillo, M.L. Kahn, S.L. Joyner, and J.M. Chatfield. 1996. Heterologous expression and characterization of soybean cytosolic ascorbate peroxidase. Arch. Biochem. Biophys. 328(1):1-8.
Das, K. and A. Roychoudhury. 2014. Reactive oxygen species (ROS) and response of antioxidants as ROS-scavengers during environmental stress in plants. Front. Environ. Sci. 2:53.

Davey, M.W., E. Stals, B. Panis, J. Keulemans, and R.L. Swennen. 2005. High-throughput determination of malondialdehyde in plant tissues. Anal. Biochem. 347(2):201-207.

Francois, L.E. 1984. Salinity effects on germination, growth, and yield of turnips. HortScience 19:82-84.

Giannopolitis, C.N. and S.K. Ries. 1977. Superoxide dismutases: II. Purification and quantitative relationship with water-soluble protein in seedlings. Plant Physiol. 59(2):315-318.

Halliwell, B. 1987. Oxidative damage, lipid peroxidation and antioxidant protection in chloroplasts. Chem. Phys. Lipids 44(2):327-340.

Chunthaburee, S., A. Dongsansuk, J. Sanitchon, W. Pattanagul, and P. Theerakulpisut. 2016. Physiological and biochemical parameters for evaluation and clustering of rice cultivars differing in salt tolerance at seedling stage. Saudi J. Biol. Sci. 23(4):467-477.

Hannachi, S. and M.C. Van Labeke. 2018. Salt stress affects germination, seedling growth and physiological responses differentially in eggplant cultivars (Solanum melongena L.). Scientia Hort. 228:56-65.

Hodges, D.M., J.M. DeLong, C.F. Forney, and R.K. Prange. 1999. Improving the thiobarbituric acid-reactive-substances assay for estimating lipid peroxidation in plant tissues containing anthocyanin and other interfering compounds. Planta 207(4):604-611.

Jan, S.A., Z.K. Shinwari, and M.A. Rabbani. 2016. Agro-morphological and physiological responses of Brassica rapa ecotypes to salt stress. Pak. J. Bot. 48(4):1379-1384.

Jana, S. and M.A. Choudhuri. 1982. Glycolate metabolism of three submersed aquatic angiosperms during ageing. Aquat. Bot. $12: 345-354$.

Jithesh, M.N., S.R. Prashanth, K.R. Sivaprakash, and A.K. Parida. 2006. Antioxidative response mechanisms in halophytes: Their role in stress defence. J. Genet. 85(3):237-254.

Keskin, S. and F. Yasar. 2007. Use of canonical correlation analysis for determination of relationships among several traits in egg plant (Solanum melongena L.) under salt stress. Pak. J. Bot. 39:1547-1552.

Li, J., J. Ma, H. Guo, J. Zong, J. Chen, Y. Wang, D. Li, L. Li, J. Wang, and J. Liu. 2018. Growth and physiological responses of two phenotypically distinct accessions of centipedegrass (Eremochloa ophiuroides (Munro) Hack.) to salt stress. Plant Physiol. Biochem. 126:1-10.

Li, Q., A. Yang, and W.H. Zhang. 2017. Comparative studies on tolerance of rice genotypes differing in their tolerance to moderate salt stress. BMC Plant Biol. 17(1):141.

Li, Y. 2009. Physiological Responses of tomato seedlings (Lycopersicon Esculentum) to salt stress. Mod. Appl. Sci. 3(3):171-176.

Liang, Y.S., H.K. Kim, A.W. Lefeber, C. Erkelens, Y.H. Choi, and R. Verpoorte. 2006. Identification of phenylpropanoids in methyl jasmonate treated Brassica rapa leaves using two-dimensional nuclear magnetic resonance spectroscopy. J. Chromatography 1112(1-2):148-155.

Liu, X. and Y. Zhang. 2016. Effects of salt stress on the enzyme activity and chlorophyll content of Potentilla fruticosa L. J. West China For. Sci. 45(4):95-100.

Luo, M.B. and F. Liu. 2011. Salinity-induced oxidative stress and regulation of antioxidant defense system in the marine macroalga Ulva prolifera. J. Exp. Mar. Biol. Ecol. 409(1):223228.

Meng, H.B., S.S. Jiang, S.J. Hua, X.Y. Lin, Y.L. Li, W.L. Guo, and L.X. Jiang. 2011. Comparison between a tetraploid turnip and its diploid progenitor (Brassica rapa L.): The adaptation to salinity stress. Agr. Sci. China 10(3):363375.

Moate, P.J., D.E. Dalley, J.R. Roche, C.B. Gow, and C. Grainger. 2002. Effects on milk production of increased dietary crude protein by feeding nitogen-fertilised turnips or lupins to dairy cows in mid-lactation. Aust. J. Exp. Agr. 42(1).

Mojarad, M.A., M.R. Hassandokht, V. abdossi, S.A. Tabatabaei, and K. Larijan. 2016. Evaluation of antioxidant enzymes activity in turnip (Brassica rapa L.) under salt stress. Intl. Res. J. Appl. Basic Sci. 10(2):132-134.

Neilsen, J.E., B.A. Rowe, and P.A. Lane. 2008. Vegetative growth and development of irrigated forage turnip (Brassica rapa L. var. rapa). Grass Forage Sci. 63(4):438-446.

Noreen, Z. and M. Ashraf. 2008. Inter and intra specific variation for salt tolerance in turnip (Brassica rapa $\mathrm{L}$.) and radish (Raphanus sativus $\mathrm{L}$.) at the initial growth stages. Pak. J. Bot. 40(1):229-236.

Noreen, Z., M. Ashraf, and N.A. Akram. 2010. Salt-induced regulation of some key antioxidant enzymes and physio-biochemical phenomena in five diverse cultivars of turnip (Brassica rapa L.). J. Agron. Crop Sci. 196(4):273-285.

Palta, J.P. 1990. Leaf chlorophyll content. Remote Sens. Rev. 5(1):207-213.

Park, H.J., W.Y. Kim, and D.J. Yun. 2016. A new insight of salt stress signaling in plant. Mol. Cells 39(6):447-459.

Parveen, T., A. Hussain, and M. Someshwar Rao. 2015. Growth and accumulation of heavy metals in turnip (Brassica rapa L.) irrigated with different concentrations of treated municipal wastewater. Hydrol. Res. 46(1):60-71.

Patra, H., M. Kar, and D. Mishra. 1978. Catalase activity in leaves and cotyledons during plant development and senescence. Biochem. Physiol. Pflanz. 172(4):385-390.

Qiu, L., Y. Huang, J. Huang, G. Xia, and N. Gong. 2006. Comparative study on vegetal and physiological characteristics of different salttolerant plants under salt stress. J. Zhejiang Univ. Sci. B 32(4):420-427.

Romero-Aranda, R., T. Soria, and J. Cuartero. 2001. Tomato plant-water uptake and plantwater relationships under saline growth conditions. Plant Sci. 160(2):265-272.

Ryu, H. and Y.G. Cho. 2015. Plant hormones in salt stress tolerance. J. Plant Biol. 58(3):147-155.

Scebba, F., L. Sebastiani, and C. Vitagliano. 2001. Activities of antioxidant enzymes during senescence of Prunus armeniaca leaves. Biol. Plant. 44(1):41-46.

Shi, Y., J. Gao, and J. Zhao. 2011. Effects of salt stress on seeds germination of turnip (Brassica rapa L.). Xinjiang Agr. Sci. 48(3):487492.

Shu, S., L.Y. Yuan, S.R. Guo, J. Sun, and Y.H. Yuan. 2013. Effects of exogenous spermine on chlorophyll fluorescence, antioxidant system and ultrastructure of chloroplasts in Cucumis sativus L. under salt stress. Plant Physiol. Biochem. 63:209-216.

Taïbi, K., F. Taïbi, L. Ait Abderrahim, A. Ennajah, M. Belkhodja, and J.M. Mulet. 2016. Effect of salt stress on growth, chlorophyll content, lipid peroxidation and antioxidant defence systems in Phaseolus vulgaris L. S. Afr. J. Bot. 105:306-312. 
Thimmaiah, S. 2004. Standard methods of biochemical analysis. Kalyani Publishers, New Delhi, India.

Tuo, X. 2016. Study on ancient cultivation techniques of organic turnip in Keping county. Seed Technol. 34(5):37.

Wang, R., S. Chen, X. Zhou, X. Shen, L. Deng, H. Zhu, J. Shao, Y. Shi, S. Dai, E. Fritz, A. Huttermann, and A. Polle. 2008. Ionic homeostasis and reactive oxygen species control in leaves and xylem sap of two poplars subjected to $\mathrm{NaCl}$ stress. Tree Physiol. 28(6):947-957.

Wang, Y., P. Stevanato, L. Yu, H. Zhao, X. Sun, F. Sun, J. Li, and G. Geng. 2017. The physiolog- ical and metabolic changes in sugar beet seedlings under different levels of salt stress. J. Plant Res. 130(6):1079-1093.

Xiong, L., K.S. Schumaker, and J.K. Zhu. 2002. Cell signaling during cold, drought, and salt stress. Plant Cell 14(Suppl.):S165-S183.

Yasin, N.A., W. Ullah Khan, Y. Ashraf, and A. Ali. 2017. Comparative physiological and morphological characterization of salt tolerance in Raphanus sativus L. J. Plant Biochem. Physiol. 5(1): 177.

Yan J., G. Li, Y. Wang, Y. Ma, and Y. Yang. 2019. Effects of salt stress on seed germination and seedling physiological characteristics of Morus mongolica. J. Agr. Sci. \& Tech. 1-10.
Ye, J. 1995. Brief history of root vegetable cultivation in China. Ancient Mod. Agr. (3):45-50.

Zeng, J., A. Chen, D. Li, B. Yi, and W. Wu. 2013. Effects of salt stress on the growth, physiological responses, and glycoside contents of Stevia rebaudiana Bertoni. J. Agr. Food Chem. 61(24):5720-5726.

Zhang P., X. Hou, and J. Wang. 2017. Causes and amelioration measures of saline-alkali land in Xinjiang region. Mod. Agr. Sci. Tech. (24):178-180.

Zhu, J.K. 2003. Regulation of ion homeostasis under salt stress. Curr. Opin. Plant Biol. 6(5):441-445.

Zhu, J.K. 2016. Abiotic stress signaling and responses in plants. Cell 167(2):313-324. 


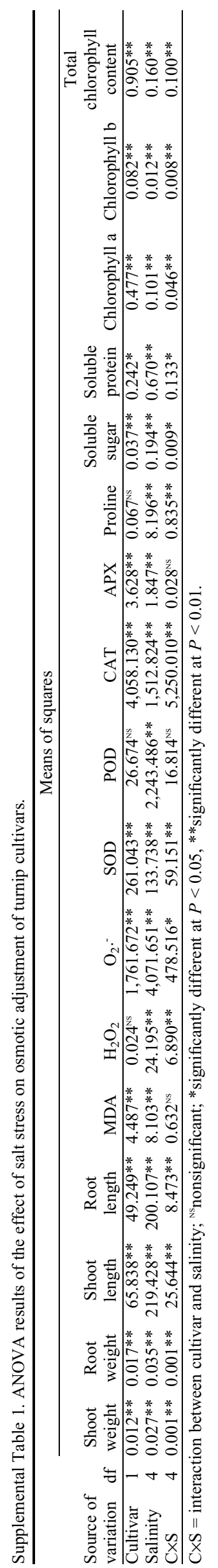

HortScience Vol. 55(10) OCtober 2020 